\title{
An Extrarenal Role for Parathyroid Hormone in the Disposal of Acute Acid Loads in Rats and Dogs
}

\author{
Donald S. Fraley and Sheldon Adler, Department of Medicine, Montefiore \\ Hospital, and the University of Pittsburgh School of Medicine, \\ Pittsburgh, Pennsylvania 15213
}

\begin{abstract}
A B S T RACT Acid infusion studies were performed in nephrectomized rats and dogs with either intact parathyroid glands (intact) or after thyroparathyroidectomy (thyroparathyroidectomized [TPTX]) to determine the role of parathyroid hormone $(\mathrm{PTH})$ in extrarenal disposal and buffering of acutely administered acid. 29 intact rats given $5 \mathrm{mM} / \mathrm{kg} \mathrm{HCl}$ and 6 intact dogs given $7 \mathrm{mM} / \mathrm{kg} \mathrm{HCl}$ developed severe metabolic acidosis but all survived. However, each of 12 TPTX rats and 4 TPTX dogs given the same acid loads died. Intact rats and dogs buffered 39 and $50 \%$ of administered acid extracellularly, respectively, whereas extracellular buffering of administered acid was 97 and $78 \%$ in TPTX rats and dogs, respectively. 17 TPTX rats and 6 TPTX dogs given synthetic PTH $2 \mathrm{~h}$ before acid infusion survived. The blood bicarbonate and extracellular buffering in these animals, measured $2 \mathrm{~h}$ after acid infusion, was similar to intact animals. Changes in liver, heart, and skeletal muscle $\mathrm{pH}$ determined from $\left[{ }^{14} \mathrm{C}\right] 5,5$-dimethyl-2,4 oxazolidinedione distribution seemed insufficient to account for the increased cell buffering of PTH-replaced animals. Indeed, muscle pH in TPTX dogs given PTH and acid was only $0.06 \mathrm{pH}$ units lower than in control dogs given no acid, suggesting that another tissue, presumably bone, was the target for PTH-mediated increased cell buffering. This conclusion was supported by the observation that PTH did not alter the $\mathrm{pH}$ of intact rat diaphragms in vitro. These results indicate that PTH is necessary for the optimal buffering of large, acute acid loads presumably by increasing bone buffering.
\end{abstract}

\section{INTRODUCTION}

Whereas most metabolic processes in the body produce hydrogen ions (1), mechanisms have evolved to prevent

This work was presented in part at the National Meeting of the American Federation for Clinical Research and published in abstract form in 1976. Clin. Res. 24: 400A.

Received for publication 27 March 1978 and in revised form 15 December 1978. their accumulation and the development of life-threatening acidosis. These mechanisms include the renal excretion of the metabolically produced hydrogen ion and the buffering of either endogenously produced or exogenously administered acid. $60 \mathrm{yr}$ ago Van Slyke and Cullen (2) first noted that the buffering of a large, acutely administered acid load was only partially accounted for by extracellular buffers. Subsequently, it was shown in $\operatorname{dog}(3)$ and man (4) that at least $50 \%$ of an acutely administered acid load was buffered intracellularly. Although these studies demonstrated the importance and extent of cellular buffering, they did not define the tissues or regulatory mechanisms involved in the buffering process. Data obtained from acid balance studies in man (5) and from bone analyses performed in acidotic animals (6) suggest that bone is the tissue primarily involved in the cellular buffering of acid in acute and chronic metabolic acidosis. Accordingly, it has been proposed that parathyroid hormone may be important for the disposal and buffering of acute acid loads (7), but exact data supporting this hypothesis are not available.

To determine whether parathyroid hormone is required for the normal tissue buffering of acid, acute acid infusion studies were performed in nephrectomized rats and dogs with intact parathyroid glands and in nephrectomized thyroparathyroidectomized rats and dogs. The effect of parathyroid hormone on intracellular skeletal muscle $\mathrm{pH}$ was also studied in vitro. The results show that parathyroid hormone is required for the optimal tissue buffering of large, acute acid loads in both animal species.

\section{METHODS}

In vivo rat studies. Male Sprague-Dawley rats weighing 375-500 g were anesthetized with Inactin (Promonta, Hamburg, West Germany). Femoral artery and central venous catheters were inserted and a tracheostomy and bilateral nephrectomy were performed. Rats were then placed on a heated, perforated board and rectal temperature was monitored throughout the experiment. After a $30-\mathrm{min}$ postoperative stabilization period, two arterial blood samples were obtained 
at 15-min intervals for blood gas determination. Only if acidbase balance and oxygenation proved stable did the animal begin a 2 -h control period. Animals not achieving such stability by $1 \mathrm{~h}$ were sacrificed. Unless otherwise specified, each animal was then given $0.5 \mathrm{~N}$ hydrochloric acid, $5 \mathrm{mmol} / \mathrm{kg}$ body wt, infused intravenously over $30 \mathrm{~min}$ followed by a $2-\mathrm{h}$ recovery period. Arterial blood gases and plasma electrolytes were determined twice during each period. In some experiments, cell $\mathrm{pH}$ was determined at the end of the stabilization period by the intravenous administration of $2 \mu \mathrm{Ci}$ of $\left[2-{ }^{14} \mathrm{C}\right]-$ 5,5-dimethyl-2,4 oxazolidinedione (DMO), ${ }^{1} 2 \mu \mathrm{Ci}$ of ${ }^{36} \mathrm{Cl}$, and $10 \mu \mathrm{Ci}$ of ${ }^{3} \mathrm{H}_{2} \mathrm{O}$.

Experiments with the above model were performed in five groups: 7 rats with intact parathyroids given no acid infusion (intact), 9 rats $1 \mathrm{~d}$ after thyroparathyroidectomy given no acid (thyroparathyroidectomized [TPTX]), 29 rats with intact parathyroids given acid (intact plus acid), 12 rats $1 \mathrm{~d}$ after thyroparathyroidectomy given acid (TPTX plus acid), and 17 rats $1 \mathrm{~d}$ after thyroparathyroidectomy given $10 \mathrm{IU} / \mathrm{kg}$ body wt of synthetic (1-34) bovine parathyroid hormone (PTH; obtained from Beckman Instruments, Inc., Spinco Div., Palo Alto, Calif.) $2 \mathrm{~h}$ before acid infusion (TPTX plus PTH plus acid). At the conclusion of the recovery period, rats were sacrificed by exsanguination from the abdominal aorta into a heparinized syringe. Skeletal muscle (gluteus), cardiac muscle, and liver were obtained for determination of intracellular $\mathrm{pH}$. A portion of each sample was used to determine tissue electrolytes.

Rat diaphragm studies. Intact rat diaphragms were obtained from 75- to 90-g non-TPTX Sprague-Dawley rats and incubated simultaneously in two boxes at $37^{\circ} \mathrm{C}$ in a modified Krebs-Ringer bicarbonate solution containing $100 \mathrm{mg} / 100 \mathrm{ml}$ of glucose and $6.25 \mathrm{mg} / 100 \mathrm{ml}$ of chloromycetin as described (8). The solution was gassed with a $4.86 \% \quad \mathrm{CO}_{2}$ balance oxygen gas mixture. Bathing solutions were changed hourly. During the final hour of incubation, $80 \mathrm{mg} / 100$ $\mathrm{ml}$ of inulin was added to each bath to measure extracellular space, and $25 \mu \mathrm{Ci}$ of $\left[2-{ }^{14} \mathrm{C}\right] \mathrm{DMO}$ was added to each solution for calculation of intracellular $\mathrm{pH}$. At the end of the experiment, diaphragms were removed alternately from the two boxes for cell $\mathrm{pH}$ determination (8). Bath $\mathrm{pH}$ was $\cong 7.00$, achieved by using a bicarbonate concentration of $10 \mathrm{meq} / \mathrm{liter}$. Incubations lasted for either 1 or $4 \mathrm{~h}$. The solution in one box contained either 10 or 100 IU/liter synthetic PTH. The other solution contained no hormone.

In vivo dog studies. Mongrel dogs weighing $10-20 \mathrm{~kg}$ were anesthetized with Diabutol (Diamond Laboratories, Des Moines, Iowa) intubated, and jugular, femoral venous, and femoral arterial catheters were inserted. Blood samples were obtained from the femoral artery. Each animal then underwent splenectomy and bilateral nephrectomy followed by a $30-\mathrm{min}$ postoperative stabilization period during which two blood samples were obtained for blood gas determinations. If these showed stability of blood acid base conditions, $50 \mu \mathrm{Ci}\left[2-{ }^{14} \mathrm{C}\right] \mathrm{DMO}, 50 \mu \mathrm{Ci}{ }^{36} \mathrm{Cl}$, and 500 $\mu \mathrm{Ci}{ }^{3} \mathrm{H}_{2} \mathrm{O}$ were given intravenously for measurement of extracellular space and intracellular $\mathrm{pH}$. A 2-h control period ensued, and blood samples were obtained at 60 and $120 \mathrm{~min}$. Hydrochloric acid, $7 \mathrm{mmol} / \mathrm{kg}$, given as a $0.3 \mathrm{~N}$ solution, was infused intravenously over $90 \mathrm{~min}$. Blood samples, hematocrit, plasma electrolytes, plasma calcium, and ${ }^{36} \mathrm{Cl}$ measurements were determined on each blood sample. Animals were

${ }^{1}$ Abbreviations used in this paper: DMO, 5,5-dimethyl-2,4 oxazolidinedione; $\mathrm{pH}_{\mathrm{i}}$, intracellular $\mathrm{pH}$; $\mathrm{PTH}$, parathyroid hormone; TPTX, thyroparathyroidectomized. sacrificed at the end of the recovery period, and skeletal muscle, liver, and heart muscle samples were obtained for cell $\mathrm{pH}$ and electrolyte determination. With this nephrectomized model four groups were studied: four dogs given no acid infusion (intact control), six dogs given $\mathrm{HCl}$ (intact plus acid), four dogs TPTX $2 \mathrm{~h}$ before the control period and then given $\mathrm{HCl}$ (TPTX plus acid), and six TPTX dogs given 10 IU of synthetic PTH/kg body wt at the beginning to the control period and then infused with $\mathrm{HCl}$ (TPTX plus PTH plus acid).

Analytic methods and calculations. The amount of acid infused was calculated from the volume and normality of the acid; the latter determined by titration of a primary Tris standard. Blood $\mathrm{pH}, \mathrm{PCO}_{2}$ and $\mathrm{PO}_{2}$ were measured on a BMS3 MK2 blood micro system (Radiometer, Copenhagen, Denmark), and the bicarbonate concentration was calculated from a standard nomogram. Plasma and tissue electrolytes were measured in an IL flame photometer (Instrumentation Laboratories, Boston, Mass.) with an internal lithium standard. Calcium was determined on a Corning (Corning Glass Works, Corning, N. Y.) calcium analyzer by photometric titration with EGTA as described by Schmidt and Reilly (9). Radioisotopes were counted in a three channel Packard liquid scintillation counter (Packard Instrument Co., Downer's Grove, Ill.). Intracellular $\mathrm{pH}$ in the nephrectomized animal studies was determined from distribution of the three isotopes with the standard equations and method described by Schloerb and Grantham (10). Intracellular $\mathrm{pH}$ in the rat diaphragm studies was determined as described (11). Chloride space measurements were made frequently in both control and recovery periods, corrected for loss of radioactivity as a result of blood removal, and used to calculate compartmental acid distribution. Total extracellular sodium, potassium, and bicarbonate in control and recovery periods were calculated as the product of the plasma concentration and the measured chloride space. At least two sets of determinations were made in each period. Extracellular buffering is defined as the reduction in total extracellular bicarbonate during the experiment. Total acid buffering is the sum of the reduction in extracellular bicarbonate plus the increase in total extracellular sodium and potassium; the latter reflecting the movement of these ions from inside the cell in exchange for extracellular hydrogen ions (12).

Data analysis. Data are presented as the mean \pm SEM. Unpaired $t$ tests were employed in all the statistical analyses.

\section{RESULTS}

\section{Rat experiments}

Stability of the rat preparation (intact group). Seven intact rats were prepared as described and observed for $6 \mathrm{~h}$. As shown in Fig. 1, blood $\mathrm{pH}$ after surgery was $7.34 \pm 0.01$ and $6 \mathrm{~h}$ later had risen to 7.39 $\pm 0.03(P<0.05)$. Simultaneously, arterial $\mathrm{PCO}_{2}$ decreased from $48 \pm 1$ to $39 \pm 5 \mathrm{~mm} \mathrm{Hg}(P<0.05)$ and blood bicarbonate fell from $25.6 \pm 0.5$ to $23.2 \pm 0.8 \mathrm{meq} / \mathrm{liter}$ $(P<0.05)$. These changes were probably the result of reversible Inactin-induced respiratory depression and a decrease in blood bicarbonate secondary to surgery and metabolic compensation for the $\mathrm{PCO}_{2}$ decrease (13). Throughout the $6 \mathrm{~h}$, blood $\mathrm{PO}_{2}$ remained constant, varying between 57 and $74 \mathrm{~mm} \mathrm{Hg}$. Mean plasma calcium concentration at the end of the control period was $4.2 \pm 0.2 \mathrm{meq} / \mathrm{liter}$. Liver, skeletal muscle, and heart 


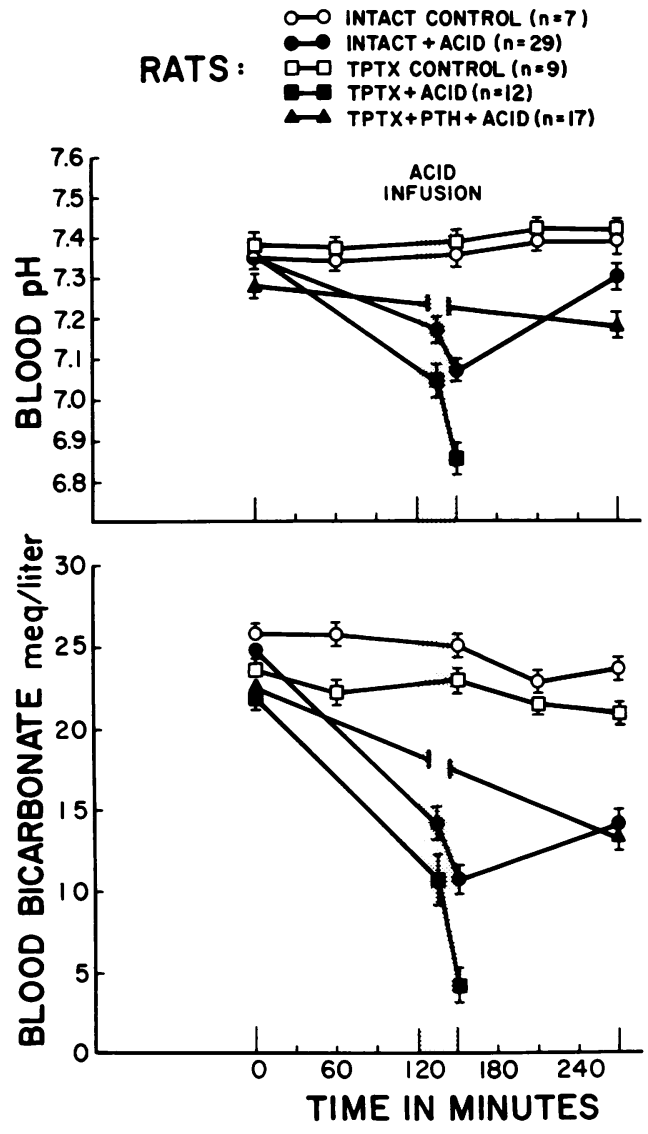

FIGURE 1 Blood pH and bicarbonate concentrations in the five groups of rats. The brackets represent \pm 1 SEM.

muscle electrolytes and $\mathrm{pH}$ are shown in Table I. They are similar to those reported by other investigators (10). The low intracellular sodium concentration, the high intracellular potassium, and the high intracellular to extracellular potassium ratio indicates maintenance of good membrane selectivity. Thus, the rat model is stable over the entire 6-h study period.

Stability of preparation in TPTX rats (TPTX group). Nine TPTX rats were observed over a 6 -h period. Fig. 1 shows that during this 6 -h period blood $\mathrm{pH}$ rose from $7.36 \pm 0.01$ to $7.40 \pm 0.02(P<0.05)$ as a result of a fall in $\mathrm{PCO}_{2}$ from $43 \pm 2$ to $34 \pm 1 \mathrm{~mm} \mathrm{Hg}(P<0.01)$. Blood bicarbonate concentartion fell from $23.4 \pm 0.9$ to 20.7 $\pm 0.7 \mathrm{meq} / \mathrm{liter}(P<0.05)$. These changes are similar to those found in the intact group. Blood $\mathrm{pH}$ at the end of $6 \mathrm{~h}$ did not differ significantly between intact and TPTX groups $(P>0.5)$, but blood bicarbonate concentration was slightly lower in the TPTX group $(P<0.05)$. To assess completeness of thyroparathyroidectomy, plasma calcium was measured at the end of the control period, and rats whose level exceeded 3.5 $\mathrm{meq} / \mathrm{liter}$ were discarded. The mean plasma calcium of $2.8 \pm 0.2 \mathrm{meq} / \mathrm{liter}$ in TPTX controls was significantly lower than the $4.2 \pm 0.2 \mathrm{meq} / \mathrm{liter}$ of the intact animals $(P<0.001)$. Table I shows the cell $\mathrm{pH}$ and tissue electrolytes in TPTX rats. Cell $\mathrm{pH}$ and intracellular sodium concentration were the same in intact and TPTX groups, but intracellular potassium concentration was lower in each tissue of the TPTX group $(P<0.05)$. Intracellular:extracellular potassium ratios, however, were virtually identical in all tissues fo the two groups. Thus, thyroparathyroidectomy did not affect membrane selectivity although it lowered the serum calcium and blood bicarbonate levels.

Intact plus acid group. 29 intact rats were given $\mathrm{HCl}$ at the end of the control period. As shown in Fig. 1 blood $\mathrm{pH}$ fell from $7.34 \pm 0.02$ to $7.07 \pm 0.02$ after acid infusion $(P<0.001)$ but rose to $7.30 \pm 0.03$ by the end of the recovery period $(P<0.001)$. Similarly, blood bicarbonate concentration fell $14.1 \mathrm{meq} / \mathrm{liter}(P<0.001)$ but rose $3.4 \mathrm{meq} / \mathrm{liter}$ during the recovery period $(P<0.01)$. Simultaneously, $\mathrm{PCO}_{2}$ decreased from $46 \pm 2$ to $35 \pm 1 \mathrm{~mm} \mathrm{Hg}$ during acid infusion $(P<0.001)$ and declined further during recovery to $32 \pm 2 \mathrm{~mm} \mathrm{Hg}$. Plasma potassium rose $1.8 \mathrm{meq} / \mathrm{liter}(P<0.001)$, and serum calcium fell from $4.6 \pm 0.2 \mathrm{meq} / \mathrm{liter}$ at the end of the control period to $4.1 \pm 0.1 \mathrm{meq} / \mathrm{liter}$ at the conclusion of the recovery period $(P<0.05)$. Cell $\mathrm{pH}$ and electrolytes were determined in 14 rats. The results are shown in Table I. The pH of each tissue studied was lower than in the intact group, but differences were not statistically significant $(P>0.1)$. Tissue potassium and sodium concentrations were slightly but not significantly lower statistically $(P>0.1)$. The decreased tissue potassium concentration and elevated plasma potassium reduced the intracellular to extracellular potassium ratio. The ratio of 21.3 in skeletal muscle, although significantly lower than in intact control rats $(P<0.001)$, is still high and demonstrates good selectivity (14). Except for an occasional surgical mortality, every rat survived the acid infusion.

TPTX rats given acid (TPTX plus acid group). 12 TPTX rats were given $\mathrm{HCl}$ after the control period. The mean plasma calcium of $3.1 \pm 0.2 \mathrm{meq} / \mathrm{liter}$ at the end of the control period was significantly lower than in the intact plus acid group $(P<0.001)$ but not significantly different from the value in TPTX rats $(P>0.1)$. Arterial blood $\mathrm{pH}$ fell during acid infusion from 7.35 \pm 0.01 to $6.84 \pm 0.03(P<0.001)$ (Fig. 1). Each of the 12 rats died before or at the completion of the acid infusion. During acid infusion, blood bicarbonate decreased $18.2 \mathrm{meq} / \mathrm{liter}$, falling from $22.1 \pm 0.5$ in the control period to $3.9 \pm 0.6 \mathrm{meq} / \mathrm{liter}$ before death $(P<0.001)$. This decrease was significantly greater than in intact plus acid rats $(P<0.001)$ despite the inability of 10 rats to complete the infusion. Even at the midpoint of acid infusion, TPTX plus acid rats had a significantly lower blood bicarbonate $(P<0.05)$. The $17-\mathrm{mm} \mathrm{Hg} \mathrm{PCO}_{2}$ drop exceeded the 11-mm $\mathrm{Hg}$ 
TABLE I

Cell $p H$ and Electrolytes in the Four Surviving Groups of Rats

\begin{tabular}{|c|c|c|c|c|c|}
\hline Tissue & $\mathrm{pH}_{\mathrm{i}}^{*}$ & $\mathrm{Na}$ & $\mathrm{K}^{*}$ & $\mathrm{~K}^{*}$ & $\mathbf{K}^{+}{ }_{\text {internal }} / \mathbf{K}_{\text {external }}^{+}$ \\
\hline & & $\begin{array}{l}\text { mequlliter } \\
\text { cell water }\end{array}$ & $\begin{array}{l}\text { meq/liter } \\
\text { cell water }\end{array}$ & $\begin{array}{l}\text { meq/kg } \\
d r y u t\end{array}$ & \\
\hline \multicolumn{6}{|l|}{ Intact $(n=7)$} \\
\hline Skeletal muscle & $6.93 \pm 0.02$ & $26.3 \pm 3.4$ & $178 \pm 6.1$ & $493.7 \pm 7.6$ & 29.2 \\
\hline Liver & $7.09 \pm 0.03$ & - & $224.1 \pm 7.2$ & $340.6 \pm 4.3$ & 36.7 \\
\hline Heart muscle & $7.08 \pm 0.04$ & $26.9 \pm 2.6$ & $151.3 \pm 5.3$ & $352.7 \pm 5.5$ & 24.8 \\
\hline \multicolumn{6}{|l|}{ TPTX $(n=9)$} \\
\hline Skeletal muscle & $6.89 \pm 0.05$ & $30.3 \pm 5.0$ & $162.4 \pm 5.3 \ddagger$ & $464.5 \pm 12.9 \ddagger$ & 29.5 \\
\hline Liver & $7.14 \pm 0.04$ & - & $205.1 \pm 3.8 \ddagger$ & $303.4 \pm 25.3 \ddagger$ & 37.3 \\
\hline Heart muscle & $7.11 \pm 0.04$ & $21.7 \pm 3.4$ & $139.1 \pm 1.9 \ddagger$ & $327.2 \pm 3.5 \ddagger$ & 25.3 \\
\hline \multicolumn{6}{|c|}{ Intact $+\operatorname{acid}(n=14)$} \\
\hline Skeletal muscle & $6.88 \pm 0.02$ & $22.7 \pm 4.2$ & $168.3 \pm 3.8$ & $475.6 \pm 12.2$ & 21.3 \\
\hline Liver & $7.03 \pm 0.03$ & - & $209.9 \pm 5.1$ & $319.8 \pm 6.3$ & 26.6 \\
\hline Heart muscle & $7.03 \pm 0.01$ & $26.7 \pm 7.0$ & $146.6 \pm 3.6$ & $345.2 \pm 8.4$ & 18.6 \\
\hline \multicolumn{6}{|c|}{ TPTX + PTH + acid $(n=7)$} \\
\hline Skeletal muscle & $6.88 \pm 0.03$ & $41.4 \pm 11.7 \ddagger$ & $144.3 \pm 10.6 \ddagger$ & $466.4 \pm 27.0$ & 20.0 \\
\hline Liver & $7.21 \pm 0.05 \ddagger$ & - & $197.9 \pm 7.2$ & $319.3 \pm 2.2$ & 27.5 \\
\hline Heart muscle & $7.03 \pm 0.03$ & $52.4 \pm 3.1 \ddagger$ & $121.0 \pm 4.8 \ddagger$ & $296.0 \pm 16.4 \ddagger$ & 16.8 \\
\hline
\end{tabular}

${ }^{*}$ Results are expressed as the mean \pm SEM.

$\ddagger$ Significantly different from intact plus acid $(P<0.05)$.

decrease in the intact plus acid group. The $100 \%$ mortality cannot, therefore, be attributed to defective respiratory compensation.

TPTX rats given PTH and acid (TPTX plus PTH plus acid group). 17 TPTX rats, given $10 \mathrm{IU} / \mathrm{kg}$ body wt of synthetic PTH at the beginning of the control period, all survived the acid infusion. The plasma calcium of $3.0 \pm 0.2 \mathrm{meq} / \mathrm{liter}$ before PTH administration was not statistically different from the other two TPTX groups $(P>0.3)$. At the end of the experiment, $6 \mathrm{~h}$ later, it had risen insignificantly to $3.2 \pm 0.2 \mathrm{meq} / \mathrm{liter}(P>0.3)$. Thus, toleration of the acid was not because of a PTHinduced rise in plasma calcium. As shown in Fig. 1, control period arterial $\mathrm{pH}$ was lower than in the other two TPTX groups $(P<0.01)$. This lower $\mathrm{pH}$ was of respiratory origin as control bicarbonate concentration in the three TPTX groups was statistically identical $(P>0.4)$. Survival of PTH-treated rats, therefore, was not the result of elevation of extracellular buffer capacity. Through a technical oversight, arterial blood samples were not drawn during acid infusion, but blood was obtained at the end of the recovery period. Arterial $\mathrm{pH}$ at the end of the recovery period was lower than in the intact plus acid group, but blood bicarbonate concentrations were identical statistically in the two groups $(P>0.4)$. The absolute decrease in the blood bicarbonate concentration in the two groups also did not differ significantly $(P>0.3)$. Assuming equal acid production, tissue buffering of infused acid was the same, therefore, in intact rats and in TPTX rats given exogenous PTH.

Acid distribution and cell buffering in intact plus TPTX rats. Extracellular buffering, as calculated from the decrease in total extracellular bicarbonate, is shown in Fig. 2. Assuming no endogenous acid production

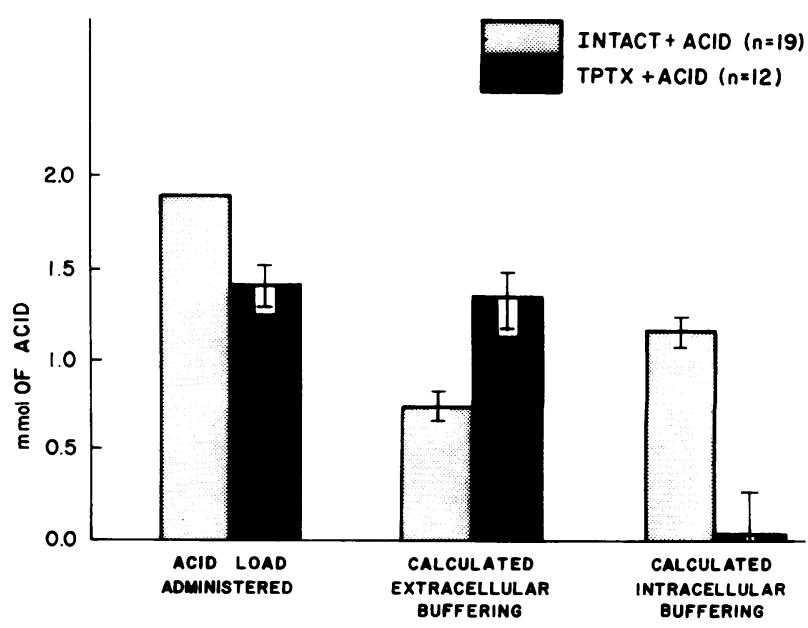

Figure 2 Distribution of acid buffering in intact plus acid and TPTX plus PTH plus acid groups. Extracellular buffering is the reduction in extracellular bicarbonate obtained by multiplying the bicarbonate concentration and the chloride space. Calculated intracellular buffering assumes no endogenous acid production. The brackets represent \pm 1 SEM. 
during the course of the experiment, $39 \%$ of administered acid was buffered extracellularly and $61 \%$, intracellularly in intact rats. These are similar to values previously reported in the dog (3). Extracellular buffering in TPTX rats was $97 \%$; significantly higher than the $39 \%$ found in the intact group $(P<0.001)$. The cellular buffering of $3 \%$ in the TPTX rats was, of course, significantly lower $(P<0.001)$. As all TPTX rats died by the end of acid infusion, no direct ${ }^{36} \mathrm{Cl}$ space measurements were obtained. Rather, the control ${ }^{36} \mathrm{Cl}$ space was assumed to have increased by the same percentage as in intact rats.

Plasma potassium values were nearly identical in the two groups surviving the acid infusion. In intact animals, plasma potassium rose from $6.1 \pm 0.1$ to 7.9 $\pm 0.3 \mathrm{meq} / \mathrm{liter}$, whereas in the TPTX group the rise was from $5.5 \pm 0.2$ to $7.2 \pm 0.4 \mathrm{meq} / \mathrm{liter}$. Final plasma potassium levels in both groups exceeded the 6 -h values found in intact and TPTX control rats $(P<0.001)$. Intracellular sodium and potassium concentrations in the two surviving TPTX groups did not differ significantly from each other except for heart muscle sodium and potassium concentration $(P<0.05)$. Small changes, however, might be missed. Table I shows that thyroparathyroidectomy per se did not affect cell $\mathrm{pH}$. It also shows that despite a slightly lower arterial blood $\mathrm{pH}$, skeletal and heart muscle $\mathrm{pH}$ values in the TPTX plus $\mathrm{PTH}$ plus acid rats were the same as in intact rats given acid $(P>0.1)$. Liver cell $\mathrm{pH}$, however, was higher in the TPTX plus PTH plus acid group $(P<0.005)$. Compared with TPTX control rats, heart muscle $\mathrm{pH}$ was significantly lower $(P<0.05)$ but insignificantly different in liver tissue $(P>0.1)$ and skeletal muscle $(P>0.5)$. Acid infusion, therefore, lowered heart muscle $\mathrm{pH}$ in intact and TPTX plus PTH rats and reduced skeletal muscle and liver cell $\mathrm{pH}$ in intact rats. However, in TPTX plus PTH rats, skeletal muscle $\mathrm{pH}$ did not fall, and liver cell $\mathrm{pH}$ rose. Thus, exogenous PTH did not appear to increase buffering of administered acid by skeletal muscle.

Rat diaphragm studies. If PTH enhances skeletal muscle buffering of administered acid, it would presumably accomplish this by increasing extracellular hydrogen ion movement into cells. Incubation of muscle in an acidic medium in the presence of the hormone would be expected, therefore, to lower muscle cell $\mathrm{pH}$. Rat diaphragms were incubated at an external $\mathrm{pH}$ of 7.00 , a value previously shown in our laboratory to reduce muscle cell $\mathrm{pH}$ in vitro and only $0.1 \mathrm{pH}$ unit lower than the blood $\mathrm{pH}$ achieved by the intact plus acid rats at the end of the acid infusion period. The effect of PTH on diaphragm muscle $\mathrm{pH}$ is shown in Table II. In each experiment, the $\mathrm{pH}$ of the incubation medium containing PTH did not differ from the control medium by more than $0.02 \mathrm{pH}$ units. The table shows that in experiments performed for $1 \mathrm{~h}$ at a PTH con-
TABLE II

Effect of PTH on the Intracellular $p H$ of Intact Rat Diaphragm Muscle In Vitro

\begin{tabular}{lccc}
\hline Group & PTH concentration* & $\mathrm{pH}_{*}$ t & $\mathrm{pH}_{i} \S$ \\
\hline & IUlliter & & \\
1-h incubation & & & \\
Control $(n=6)$ & 0 & 7.04 & $7.04 \pm 0.03$ \\
PTH $(n=6)$ & 10 & 7.03 & $7.02 \pm 0.04$ \\
4-h incubation & & & \\
Control $(n=12)$ & 0 & 7.00 & $7.00 \pm 0.05$ \\
PTH $(n=12)$ & 10 & 6.99 & $7.00 \pm 0.02$ \\
1-h incubation & & & \\
Control $(n=12)$ & 0 & 7.04 & $7.01 \pm 0.03$ \\
PTH $(n=12)$ & 100 & 7.02 & $7.00 \pm 0.05$ \\
\hline
\end{tabular}

* Synthetic (1-34) bovine PTH.

\& Extracellular pH.

$\S$ Results expressed as the mean \pm SEM.

centration of $10 \mathrm{IU} /$ liter, there was no significant difference in the $\mathrm{pH}$ of tissues incubated with the hormone compared with those incubated without hormone $(P>0.3)$. Increasing incubation time fourfold or raising the PTH concentration 10 -fold to 100 IU/liter had no statistically significant effect on cell $\mathrm{pH}(P>0.5)$. Tissue sodium and potassium concentrations were identical in tissues incubated with or without PTH, whereas the intracellular:extracellular potassium ratio in each experiment exceeded 20. Exogenous PTH, therefore, does not alter diaphragm muscle cell $\mathrm{pH}$ in vitro.

\section{Dog experiments}

Stability of the dog preparation (intact control). Four nephrectomized, splenectomized dogs with intact parathyroids were followed for $5.5 \mathrm{~h}$. Fig. 3 shows that blood $\mathrm{pH}$ increased insignificantly from $7.36 \pm 0.03$ to $7.41 \pm 0.03(P>0.05)$, and the $\mathrm{PCO}_{2}$ also fell insignificantly $(P>0.1)$. Despite minor variations, blood bicarbonate concentration also was unaltered $(P>0.05)$. Plasma sodium and potassium concentrations of $144 \pm 3$ and $3.1 \pm 0.6 \mathrm{meq} / \mathrm{liter}$ also remained unaltered $(P>0.1)$. After $5.5 \mathrm{~h}$, animals were sacrificed, and tissues were obtained for measurement of intracellular $\mathrm{pH}$. Liver cell $\mathrm{pH}$ was $7.03 \pm 0.06$, heart $\mathrm{pH}$ was 6.92 \pm 0.03 , and skeletal muscle $\mathrm{pH}$ was $6.98 \pm 0.02$; values similar to ones previously reported in rat, dog, and man (10). Thus, extracellular and intracellular acid base conditions were stable over $5.5 \mathrm{~h}$.

Acid infusion in intact parathyroid dogs (intact plus acid). Fig. 3 shows that blood $\mathrm{pH}$ fell rapidly during acid infusion $(P<0.001)$ because of a decrease in blood bicarbonate of $15.2 \mathrm{meq} / \mathrm{liter}(P<0.001)$. Respiratory compensation occurred in all animals with a mean $\mathrm{PCO}_{2}$ decrease of $15 \mathrm{~mm} \mathrm{Hg}(P<0.001)$. All six dogs 


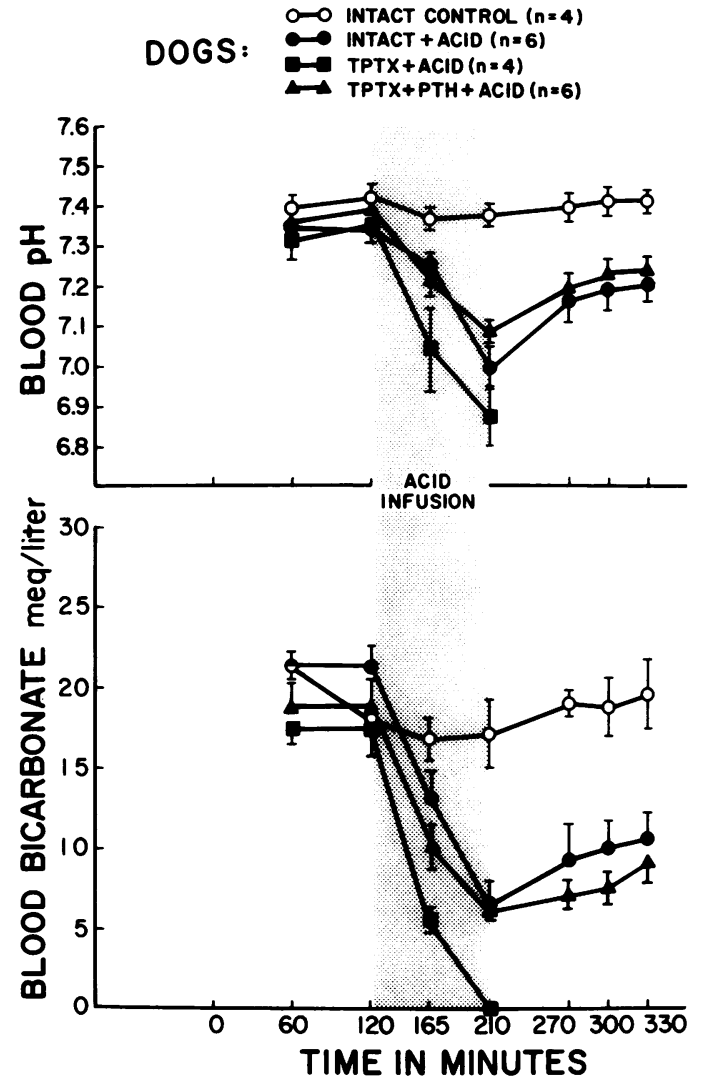

FIGURE 3 Blood $\mathrm{pH}$ and bicarbonate concentrations in the four groups of dogs. The brackets represent \pm 1 SEM.

survived the acid infusion. During the 2-h recovery period, blood $\mathrm{pH}$ and bicarbonate rose $0.21 \mathrm{U}$ and 4.5 meq/liter, indicating tissue generation of bicarbonate. Plasma sodium concentration decreased from $143 \pm 4$ to $136 \pm 3 \mathrm{meq} / \mathrm{liter}(P<0.05)$, whereas plasma potassium concentration rose from $3.3 \pm 0.2$ to $6.2 \pm 0.5 \mathrm{meq} / \mathrm{liter}$ $(P<0.001)$. Plasma calcium concentration at the end of the control period was $4.2 \pm 0.3 \mathrm{meq} / \mathrm{liter}$. At the end of the recovery period, liver cell $\mathrm{pH}$ was $7.00 \pm 0.03$, heart muscle $\mathrm{pH}$ was $6.84 \pm 0.02$, and skeletal muscle $\mathrm{pH}$ was $6.82 \pm 0.03$.

Acid-infused TPTX dogs (TPTX plus acid). Four TPTX dogs were given $\mathrm{HCl}$. At the end of the control period, the mean plasma calcium concentration of 2.3 $\pm 0.5 \mathrm{meq} / \mathrm{liter}$ was significantly lower $(P<0.001)$ than in intact animals. Each dog died before completion of the acid infusion despite marked respiratory compensatory effort. As shown in Fig. 3, control period blood $\mathrm{pH}$ in these dogs did not significantly differ from that of intact control $(P>0.5)$ or intact plus acid dogs $(P>0.5)$. Control period blood bicarbonate concentration, however, was significantly lower in the TPTX animals $(P<0.01)$. After acid infusion, blood bicarbon- ate fell $16.9 \mathrm{meq} /$ liter $(P<0.001)$ to unmeasurable levels at the time of death. The absolute drop in blood bicarbonate concentration was greater in the TPTX than in the intact plus acid dogs $(P<0.02)$. Control plasma sodium levels of $133 \pm 3$ meq/liter were significantly lower than in either intact dog group $(P<0.001)$, but the plasma potassium level of $3.2 \pm 0.5 \mathrm{meq} / \mathrm{liter}$ did not differ from the other groups $(P>0.5)$. All animals died, so no tissues were obtained for cell $\mathrm{pH}$. This $100 \%$ mortality was identical to that found in TPTX plus acid rats. To determine whether exogenous PTH would also prevent death in dogs, TPTX dogs were given PTH before receiving the acid infusion.

Acid infusion in TPTX dogs given exogenous PTH (TPTX plus PTH plus acid). Six dogs were given PTH at the beginning of the control period and $2 \mathrm{~h}$ later given $\mathrm{HCl}$. Fig. 3 shows that control arterial blood $\mathrm{pH}$ did not differ significantly $(P>0.4)$ from the previous three groups, whereas control period blood bicarbonate concentration was the same as in the TPTX plus acid group $(P>0.1)$. After acid infusion, blood $\mathrm{pH}$ fell 0.24 $\mathrm{U}(P<0.001), \mathrm{PCO}_{2}$ decreased $11 \mathrm{~mm} \mathrm{Hg}(P<0.001)$, and blood bicarbonate fell $12.2 \mathrm{meq} /$ liter $(P<0.001)$. All six dogs survived, and during the recovery period, blood $\mathrm{pH}$ and bicarbonate rose $0.08 \mathrm{U}$ and $1.6 \mathrm{meq} / \mathrm{liter}$, respectively. Plasma calcium at the end of the control period was $2.8 \pm 0.2 \mathrm{meq} / \mathrm{liter}$; significantly less than in intact dogs $(P<0.001)$ but not different from the level in the TPTX groups $(P>0.05)$. Plasma sodium concentration fell from $136 \pm 1$ to $133 \pm 1$ meq/liter, whereas plasma potassium rose from $3.4 \pm 0.4$ to $5.4 \pm 0.5 \mathrm{meq} /$ liter. Liver cell $\mathrm{pH}$ was $7.06 \pm 0.02$, heart muscle $\mathrm{pH}$ was $6.89 \pm 0.04$, and skeletal muscle $\mathrm{pH}$ was $6.92 \pm 0.03$ at the time of sacrifice. Fig. 3 shows that even midway during acid infusion, at least $30 \mathrm{~min}$ premortem, blood bicarbonate decreases in the three acid infused groups differed. In intact plus acid and TPTX plus PTH plus acid dogs, blood bicarbonate had fallen 7.6 and 8.2 meq/liter compared with 11.9 meq/liter in the TPTX plus acid group. The $50 \%$ greater decrease in the latter group's blood bicarbonate at $\mathbf{4 5} \mathrm{min}$ was significantly different from the two other groups $(P<0.001)$. For the entire experiment, the overall decrease in blood bicarbonate in intact plus acid and TPTX plus PTH plus acid groups of 10.7 and $10.6 \mathrm{meq} / \mathrm{liter}$ was virtually identical $(P>0.5)$.

Distribution of infused acid in dogs (body buffering). Calculation of extracellular and intracellular buffering requires a reproducible measure of extracellular space. Although a small amount of chloride is located intracellularly, changes in its distribution reflect changes in extracellular space (15). Whatever substance is used, the results obtained must be reproducible. The reproducibility of the chloride spaces in the present experiments is shown in Table III. At the end of the 
TABLE III

Chloride Spaces in the Four Groups of Dogs*

\begin{tabular}{lccccc}
\hline \multicolumn{1}{c}{ Group } & Body weight & Period 1t & Period 2\$ & Period 3" & $\begin{array}{c}\text { Percent increase } \\
\text { over entire } \\
\text { experiment }\end{array}$ \\
\hline & $k g$ & $m l$ & $m l$ & $m l$ & $\%$ \\
Intact control & $15.7 \pm 0.3$ & $5,239 \pm 611$ & $5,435 \pm 730$ & $5,663 \pm 727$ & 8.1 \\
Intact + acid & $14.9 \pm 1.0$ & $4,757 \pm 648$ & $5,465 \pm 457$ & $5,614 \pm 839$ & 18.0 \\
TPTX + acid & $15.1 \pm 1.7$ & $4,802 \pm 596$ & $5,660 \pm 624$ & - & - \\
$\begin{array}{c}\text { TPTX + PTH } \\
\text { + acid }\end{array}$ & $17.6 \pm 0.9$ & $5,673 \pm 1,050$ & $6,564 \pm 482$ & $6,672 \pm 1,058$ & 17.6 \\
\hline
\end{tabular}

* Values are given as the mean \pm SEM.

I Values were obtained at the end of the 2-h control period and are the mean of two determinations in each dog.

$\$$ Values were obtained after acid infusion in the last three groups and are the mean of two determinations in each dog.

"Values were obtained at the completion of the recovery period in the second and fourth groups of dogs.

They are the mean of three determinations in each dog.

control period, chloride spaces were $33,33,32$, and $32 \%$ of body wt, indicating identity among groups. During the next $90 \mathrm{~min}$, intact control dogs received a maintenance $5 \%$ dextrose infusion while the other three groups received hydrochloric acid. Extracellular space increased $4 \%$ in the intact controls and $15 \%$ in each of the three acid-infused groups. Throughout the recovery period, the three surviving groups of dogs received a 5\% dextrose infusion, and chloride space increased $4.2,2.7$, and $1.7 \%$ in these groups.

The buffering distributions shown in Table IV were calculated from the measured chloride spaces. Intact control animals, although receiving no acid, demonstrated some buffering. Presumably, this was a result of endogenous acid production in a catabolic postoperative dog, although penetration of chloride into cells cannot be completely ruled out. The small change in total extracellular bicarbonate suggests that this latter effect, if present, was small. Calculated endogenous acid production rate was $\cong 3.5 \mathrm{meq} / \mathrm{kg}$ body wt. Buffering in each acid-infused group exceeded the amount of acid administered. Differences between calculated buffering and administered acid in the two groups surviving acid infusion were less than the buffering shown by intact control animals and presumably represent endogenous acid production. The greater excess in the TPTX plus acid animals is explained by leakage of sodium from the erythrocytes of dying animals (16). This conclusion is supported by the observation that the excess in total buffering was completely accounted for by increased extracellular sodium as changes in extracellular potassium were equal in the three acid-infused groups $(P>0.4)$. Dog erythrocytes are high in sodium and low in potassium

TABLE IV

Distribution of Buffering in the Four Groups of Dogs*

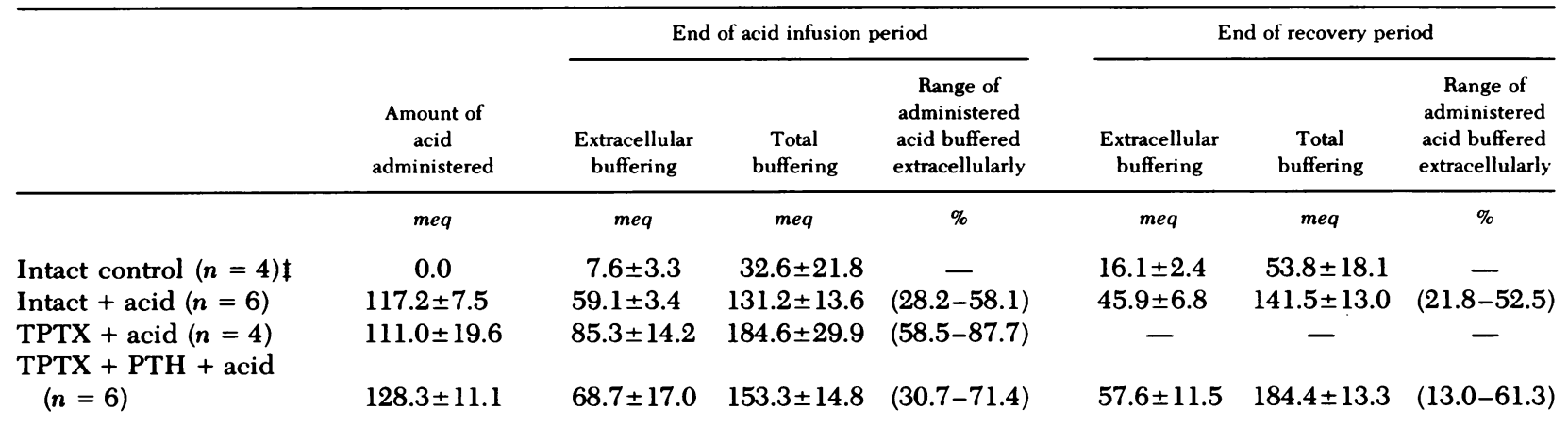

* All values are given as the mean $\pm \mathrm{SEM}$.

† No acid infusion. 
(17), whereas all other cells have a high potassium content, so erythrocytes must have released sodium into the extracellular fluid. The amount of acid administered toTPTX plus acid dogs was less than in the other two groups because all dogs died before completion of the acid infusion. Table IV shows that during the recovery period total extracellular bicarbonate decreased by $8.5 \mathrm{meq}$ in the intact controls but rose 13.2 and $11.1 \mathrm{meq}$ in the intact plus acid and the TPTX plus PTH plus acid groups, demonstrating cellular bicarbonate generation.

Extracellular buffering differed markedly among groups. The percent of administered acid buffered extracellularly exceeded $50 \%$ in all four TPTX plus acid dogs but in only one dog in each of the other two acid-infused groups. Fig. 4 shows that $\cong 50 \%$ of administered acid in the intact and PTH-replaced groups was buffered extracellularly compared with nearly $80 \%$ in the TPTX plus acid group $(P<0.001)$. This difference is not just a premortem phenomenon, as Fig. 3 demonstrates that the extracellular bicarbonate concentration at the midpoint of the infusion period in the TPTX plus acid group was already significantly lower than in the other two acid-infused groups $(P<0.001)$. Chloride space changes were similar in the three groups, so the greater fall in blood bicarbonate in the TPTX group reflects increased extracellular buffering. Thus, extracellular buffering was elevated, and cellular buffering diminished in TPTX plus acid dogs. Fig. 4 and Table IV also show that by the end

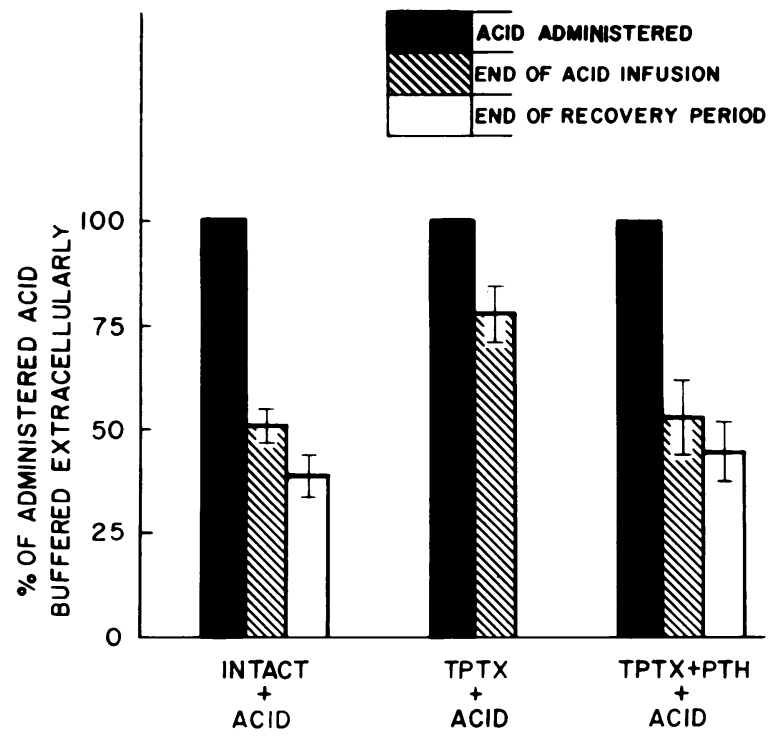

Figure 4 Percent of administered acid buffered extracellularly at the end of the acid infusion and at the end of the recovery period in the intact plus acid, TPTX plus acid, and TPTX plus PTH plus acid groups of dogs. The brackets represent \pm 1 SEM. of the recovery period extracellular buffering accounted for $<50 \%$ of the administered acid in the intact plus acid and TPTX plus PTH plus acid groups.

The data shown in Table $\mathrm{V}$ suggest that the cellular site of PTH-mediated cellular buffering is not liver, heart, or skeletal muscle. Despite a significant drop in blood $\mathrm{pH}$ in intact plus acid and TPTX plus PTH plus acid groups, liver cell $\mathrm{pH}$ in these groups did not differ significantly from intact controls $(P>0.3)$. Heart muscle $\mathrm{pH}$ did fall significantly in the intact plus acid group but not in the TPTX plus PTH plus acid dogs. Skeletal muscle $\mathrm{pH}$ decreased significantly in the two acid-infused groups, but the decrease in the PTH-replaced group was only $0.06 \mathrm{pH}$ units $(P<0.05)$. It seems unlikely that such small changes are responsible for the calculated cellular buffering of 6.4 and 7.3 meq/kg body wt (Table V) that occurred in the intact plus acid and the TPTX plus PTH plus acid groups.

\section{DISCUSSION}

Daily net acid balance (18) may be upset either by a reduction in renal hydrogen ion secretory capacity, as in patients with chronic renal disease (19), or by the sudden presentation of large acid loads exceeding the kidney's ability to sufficiently increase acid excretion. In the latter situation, the body buffers the excess acid. Early experiments suggested that skeletal muscle, and presumably other tissue membranes, were impermeable to extracellular hydrogen and(or) hydroxyl ions (20). Subsequent work, however, demonstrated that the internal $\mathrm{pH}$ of muscle was responsive to changes in external hydrogen ion activity (11). Indeed, after acute acid administration $>50 \%$ of the administered acid is buffered intracellularly $(3,4)$. Also, during intermittent acid infusion, although extracellular bicarbonate is the major buffer, cellular buffers restore extracellular bicarbonate concentration in the interinfusion periods (21). Yoshimura et al. (22) showed that in the first $24 \mathrm{~h}$ after a large acid infusion, dogs excreted only $25 \%$ of

TABLE V

Cell pH in the Surviving Three Groups of Dogs*

\begin{tabular}{lccc}
\hline Group ( $n$ value) & Liver $\mathrm{pH}_{\mathrm{i}}$ & $\begin{array}{c}\text { Skeletal } \\
\text { muscle } \\
\mathrm{pH}_{\mathrm{i}}\end{array}$ & $\begin{array}{c}\text { Heart } \\
\text { muscle } \\
\mathrm{pH}_{\mathrm{i}}\end{array}$ \\
\hline $\begin{array}{c}\text { Intact control } \\
(n=4)\end{array}$ & $7.03 \pm 0.06$ & $6.98 \pm 0.02 \ddagger$ & $6.92 \pm 0.03 \ddagger$ \\
$\begin{array}{c}\text { Intact }+ \text { acid } \\
(n=6)\end{array}$ & $7.00 \pm 0.03$ & $6.82 \pm 0.03$ & $6.84 \pm 0.02$ \\
$\begin{array}{c}\text { TPTX }+ \text { PTH } \\
+ \text { acid }(n=6)\end{array}$ & $7.06 \pm 0.02$ & $6.92 \pm 0.03 \ddagger$ & $6.89 \pm 0.04$ \\
\hline
\end{tabular}

* Results are expressed as the mean $\pm \mathrm{SEM}$.

$\ddagger$ Significantly different from intact plus acid $(P<0.05)$. 
the administered acid. Nevertheless, after $24 \mathrm{~h}$, the blood bicarbonate concentration had returned to its control value. Over the next $6 \mathrm{~d}$ the remaining acid was excreted, suggesting slow release of the acid from intracellular buffer sites.

Although these studies demonstrate the extent of cellular buffering, they do not define its location or regulation. Burnell (23) found decreased bone carbonate in dogs with metabolic acidosis, whereas Bergstrom (6) noted reduced bone sodium, calcium, and carbonate concentrations in metabolic acidosis, suggesting titration of bone buffers by acid. Studies in normal and uremic human volunteers (5) also support the concept that bone is a major tisssue buffer. PTH as a major regulator of bone metabolism (24) might, therefore, be involved in bone buffering. Indeed, parathyroid glands appeared late in evolution, almost $200,000,000 \mathrm{yr}$ after the appearance of fish with a calcium skeleton. Wills (7) and Wachman and Bernstein (25), noting that vitamin $\mathrm{D}$ and calcitonin efficiently regulate calcium balance in bony fish, questioned the sudden appearance of parathyroid glands in amphibia. As amphibia were no longer able to efficiently transfer hydrogen ions into the surrounding sea, despite the continued necessity to dispose of metabolic acid, they proposed that the primary evolutionary function of PTH was to mobilize bone phosphate and carbonate, thereby providing the body with a reserve of phosphate ions and buffer. PTH also has many renal actions that affect net acid excretion and acid base balance (26-28), and one study even suggests circulating PTH levels are increased in acidosis (29). Finally, bone resorption after PTH administration may be mediated through changes in local acidity. Acetazolamide blockade of carbonic anhydrase, an enzyme present in rat osteoclasts, prevents PTHstimulated bone resorption in rats (30). The hypercalcemic response of rats to dibutyryl cyclic $3^{\prime} 5^{\prime}$-AMP is also blocked by acetazolamide, suggesting that the final mediator of PTH-stimulated bone resorption is the local $\mathrm{pH}$ environment (31). In addition, recent experiments by Martin et al. (32) have demonstrated that both the uptake and biological effect of PTH in an isolated, perfused canine-bone preparation is enhanced by acidosis.

These experiments support the hypothesis that PTH is important for tissue buffering after acute acid administration. All 16 TPTX rats and dogs given acid died, whereas the 35 animals with intact parathyroids given the same acid dose survived. Reduction of extracellular bicarbonate was significantly greater in TPTX animals even after reception of only one-half of the acid load. Differences might have been larger if TPTX animals had received all the acid, but 14 animals died before completion of the infusion. Each animal was nephrectomized, so changes in acid excretion cannot explain this observation. There are two possible explanations. First, endogenous lactic acid production might have increased in TPTX animals. Although this possibility cannot be totally excluded, it seems unlikely. Oxygen tension in the TPTX animals remained constant, $\mathrm{CO}_{2}$ retention did not develop, and the anion gap was identical in all groups. Additionally, blood pressure measurements every $15 \mathrm{~min}$ were relatively constant, and hypotension developed only near death long after bicarbonate had fallen more sharply in the TPTX rats and dogs. The alternative explanation is that cellular buffering differed in the two groups. The calculation of extracellular and cellular buffering depicted in Figs. 2 and 4 supports this conclusion. Reduced tissue buffering in TPTX animals presumably resulted in depletion of extracellular buffer stores, acidosis, and death. Acid distribution was not precisely measured in the TPTX plus acid rats as extracellular space, and transcellular shifts of sodium and potassium were not determined. However, such measurements were made in the dogs. Cellular buffering is calculated from the difference between total buffering and extracellular buffering (3), and determination of the latter requires a reproducible measure of changes in extracellular space. The chloride space values found in the present experiments (Table IV) are higher than those previously reported by other investigators (33), a variance for which we have no explanation. This difference is unimportant, however, as it is the change in extracellular space, not the absolute space, that determines extracellular buffering. Control period chloride spaces were high but equivalent in each of the four groups studied, so reducing the control chloride space from 33 to $20 \%$ did not significantly affect the extent of calculated extracellular buffering. In addition, the changes in chloride space measured after acid administration were virtually identical to those reported by other investigators using inulin, radiosulfate, or chloride spaces $(3,21,22)$, and the percentage of administered acid buffered extracellularly in the intact dogs was the same as that reported in other studies $(3,21,22)$.

The reduced cellular buffering induced by thyroparathyroidectomy could be the result of reduced tissue buffer capacity, altered plasma calcium concentration, thyroid hormone deficiency, or PTH deficiency. The effect of thyroparathyroidectomy on tissue electrolytes and intracellular $\mathrm{pH}$ is not known. In this study thryoparathyroidectomy performed $24 \mathrm{~h}$ earlier in control rats did not significantly alter the cell $\mathrm{pH}$ or electrolyte content of skeletal muscle, cardiac muscle, or liver. Bone $\mathrm{pH}$ is not yet measurable (34) so the effect of thyroparathyroidectomy on bone buffering capacity was not determined. Given the enormous buffer capacity of bone (35), it is unlikely that a change in this quantity could explain the observed results. Reduced 
tissue buffering capacity, therefore, cannot account for diminished cellular buffering in TPTX animals. Plasma calcium was low in TPTX animals, and calcium ions are involved in a host of biochemical reactions that might affect cellular buffering (36). Calcium, for example, increases the permeability of sea urchin eggs to sodium, increases hydrogen ion efflux, and raises the intracellular $\mathrm{pH}$ of the eggs (37). The lowered plasma calcium level, however, did not appear responsible for the reduced cell buffering because exogenous PTH restored cellular buffering in TPTX animals without significantly altering plasma calcium. For the same reason, it is unlikely that thyroid hormone deficiency reduced tissue buffering. Also, hypothyroidism is unassociated with significant abnormalities in acid base balance. The most likely explanation is that PTH is necessary for optimal tissue buffering of acutely administered acid, as TPTX animals given exogenous PTH buffered the infused acid in a manner similar to intact animals. Although other factors not examined might be involved in the reduced cellular buffering seen after thyroparathyroidectomy, it seems that PTH is a prime mediator in the buffering of a large, acute acid load.

At least two factors determine the extent of cellular buffering. The first is the time elapsed after acid infusion. Schwartz et al. (21) and Yoshimura et al. (22) showed that the percentage of administered acid buffered intracellularly increased progressively with time. The cellular generation of bicarbonate during the recovery period exemplifies this relationship. Inasmuch as blood bicarbonate fell more rapidly in TPTX than in intact dogs (Fig. 3), it seems cell buffers did not become increasingly available in TPTX dogs during the infusion period. A second factor that regulates cell buffering is extracellular buffering capacity. The greater the severity of the metabolic acidosis, the more the buffer requirement for correction of the acidosis exceeds the value predicted from the fall in blood bicarbonate concentration (38). This is a result of increased cell buffering. In addition, the bicarbonate distribution space increases when extracellular buffering capacity is lowered by inducing either a metabolic acidosis $(39,40)$ or a respiratory alkalosis (41). Reducing extracellular buffering capacity, therefore, increases the percentage of cell buffering, and if cell buffering mechanisms are intact, relative cellular buffering will increase as extracellular bicarbonate falls. To examine this relationship in the present experiments, the minimum blood bicarbonate concentration reached after acid infusion in the individual animals is plotted as a function of the percent of administered acid buffered extracellularly. The data are shown in Fig. 5. The horizontal line at the $50 \%$ level was drawn to indicate the usual degree of extracellular buffering of an acute acid load (3).

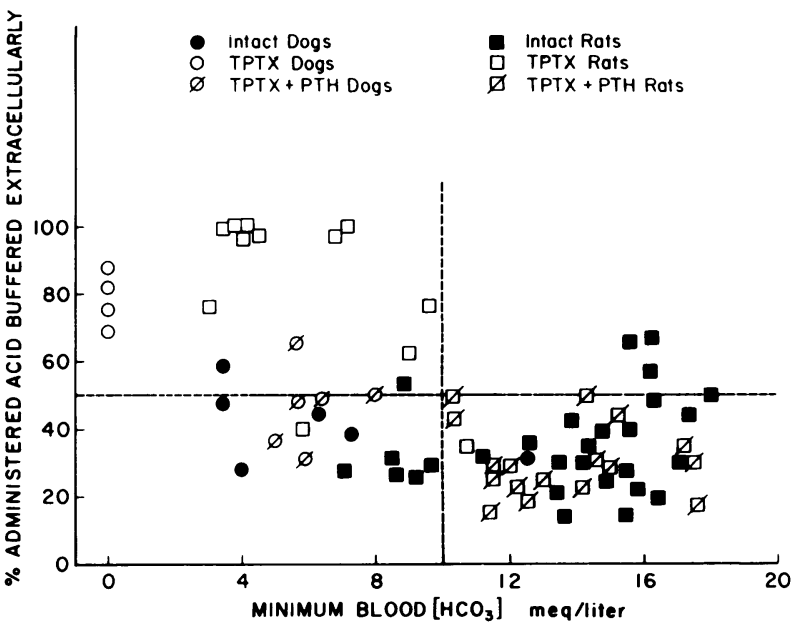

FIGURE 5 The percent of administered acid buffered extracellularly vs. the minimum blood bicarbonate concentration achieved in the three groups of dogs and three groups of rats which received acid infusions.

Points falling below this line indicate increased cellular buffering, whereas those above it suggest reduced cellular buffering. The vertical line drawn at a bicarbonate concentration of $10 \mathrm{meq} / \mathrm{liter}$ is equal to one-half the control period value of all the dogs studied. Values to the left of this line indicate more severe reductions in extracellular buffering capacity. Despite the greater lowering of blood bicarbonate in the TPTX animals, relative extracellular buffering was increased. Of the 17 points in the upper left quadrant, representing animals with the greatest reductions in both blood bicarbonate and cellular buffering, 14 are non-PTH-replaced TPTX animals. Only two TPTX animals do not fall into this quadrant. In contrast, only 3 of 59 intact or PTHreplaced animals are represented in this group. Furthermore, each of the 11 animals whose extracellular buffering exceeded $75 \%$ of the acid load were TPTX animals. As control blood bicarbonate levels are higher in rats than in dogs, we examined the relationship of cell buffering to the percent reduction in control bicarbonate. Although not shown, these data are virtually identical to those shown in Fig. 5. Thus, cell buffering is reduced in both TPTX rats and dogs despite the greater decrease in extracellular buffering capacity. The large variations between animals probably reflect individual differences in extracellular and cellular buffering capacity, body mass, respiratory compensation, penetration of hydrogen ions into cells, or other factors.

The data suggest that bone is the target tissue for the cellular buffering action of PTH. All tissues participate in buffering (42) but either because of size or metabolic function the major tissue buffers are muscle, liver, and 
bone. The in vitro rat-diaphragm data suggest that PTH does not directly affect skeletal muscle cell $\mathrm{pH}$, although it is recognized that small amounts of hydrogen ion could be buffered without a measurable change in cell $\mathrm{pH}$. The conclusion that PTH does not affect skeletal muscle cell $\mathrm{pH}$ is further supported by the in vivo data showing that skeletal muscle $\mathrm{pH}$ was only minimally reduced and that heart muscle $\mathrm{pH}$ did not differ between the intact and TPTX plus PTH-acidinfused rats or dogs. Liver $\mathrm{pH}$ in dogs also did not differ between the same groups. Liver cell $\mathrm{pH}$ was significantly elevated in the TPTX plus PTH plus acid rats compared with intact plus acid rats (Table I). As thyroparathyroidectomy per se did not alter liver cell $\mathrm{pH}$, the rise in liver cell $\mathrm{pH}$ despite a lower extracellular blood $\mathrm{pH}$ suggests that $\mathrm{PTH}$ administration influenced liver cell buffering. Cohen et al. (43) have shown that when circulating lactate is taken up and metabolized by the liver, liver cell $\mathrm{pH}$ is raised. It is possible that PTH increased the liver uptake of lactate and prevented the development of lactic acidosis (44). Although such an action of PTH could be important, it does not explain the reduction in cellular buffering induced by thyroparathyroidectomy. Constancy of cell $\mathrm{pH}$ does not rule out buffering by these tissues because a fall in carbon dioxide tension might maintain cell $\mathrm{pH}$ constant despite a drop in tissue bicarbonate (45). Quantitatively, however, this possibility can be excluded. Cell water is $\cong 35 \%$ of body wt (45), most of which is in skeletal muscle. Skeletal muscle bicarbonate concentration in the control dogs, calculated from the $\mathrm{PCO}_{2}$ of $32 \mathrm{~mm} \mathrm{Hg}$ and the intracellular $\mathrm{pH}\left(\mathrm{pH}_{\mathrm{i}}\right)$ of 6.98 , was $7.2 \mathrm{meq} / \mathrm{liter}$ at the conclusion of the experiment. By the end of the acid infusion, the PTH-replaced dogs, with a calculated cell water of 6 liters, had buffered 71 meq of administered acid intracellularly. Even if the assumption is made that $50 \%$ of tissue buffering is by nonbicarbonate buffers (3) then 35 meq of administered acid in the TPTX plus PTH plus acid dogs would have titrated cellular bicarbonate and lowered its concentration to $1 \mathrm{meq} / \mathrm{liter}$. The actual value, however, calculated from the measured $\mathrm{PCO}_{2}$ of $21 \mathrm{~mm} \mathrm{Hg}$ and $\mathrm{pH}_{\mathrm{i}}$ of 6.92 was $4.5 \mathrm{meq} / \mathrm{liter}$. These calculations underestimate the amount of tissue buffering because they neglect endogenous acid production. When this is included, the theoretical intracellular bicarbonate concentration approaches zero. In addition, decreased $\mathrm{PCO}_{2}$ lowers tissue bicarbonate concentration (41), and the fall in $\mathrm{PCO}_{2}$ from 32 to $20 \mathrm{~mm} \mathrm{Hg}$ accounts for at least part of the drop in the muscle bicarbonate concentration after acid infusion. The observed change in muscle cell bicarbonate is less than that predicted from previous estimates of muscle buffering capacity (14). Roos (46) estimated soft tissue buffering capacity at $3.6-4.2 \mathrm{meq} / \mathrm{kg}$ body wt. By using this value and the arterial $\mathrm{PCO}_{2}$ levels in our dogs, it can be calculated that only $27-37 \%$ of the observed cellular buffering is accounted for by soft tissue buffering. Although changes in metabolic disposal of acid cannot be ruled out, the data are most consistent with the conclusion that another tissue, presumably bone, was responsible for most of the PTH-induced buffering. Exogenous PTH was administered only $2 \mathrm{~h}$ before the acid infusion; but in bone (47), PTH-stimulated cyclic AMP generation occurs well within this time period. As cell $\mathrm{pH}$ in the three tissues studied was higher in PTHreplaced dogs than in intact dogs at the end of the recovery period, despite an equivalent degree of cell buffering, it appears that exogenous PTH increased bone buffer availability. Whether larger amounts of PTH would further enhance tissue buffering cannot be predicted from the present work. Some studies of the action of PTH on proximal tubular bicarbonate reabsorption suggest, for example, that only a minimum amount of hormone needs to be present and that increasing amounts have little further effect (48).

PTH-regulated tissue buffering may be important clinically. Thus, patients with chronic renal failure are often in positive acid balance (19) and exhibit bone pathology (5). It has been proposed that in these patients the bone is titrated by the retained acid. Because PTH levels are elevated in chronic renal failure (49), increased PTH could increase bone buffering as it did in the present studies. However, the present work only examined acute metabolic acidosis, and the results cannot be extrapolated to the chronic state. Also, as mentioned earlier, no data have been obtained showing whether PTH-mediated buffering is dose related. Studies must still be done to determine whether PTH regulates tissue buffering in chronic as well as acute metabolic acidosis. The results, however, indicate that PTH is an important component of the body's defense against life-threatening, acute metabolic acidosis.

\section{ACKNOWLEDGMENTS}

The authors are extremely grateful to Miss Barbara Zett and Miss Kathleen Harcharik for their invaluable technical assistance and wish to thank Mrs. Elaine R. New for her assistance in manuscript preparation.

This work was supported in part by National Institutes of Health grant 9 ROI AM17793-04.

\section{REFERENCES}

1. White, A., P. Handler, and E. L. Smith. 1964. Principles of Biochemistry. McGraw-Hill Book Company, New York. $362-557$.

2. Van Slyke, D. C., and G. E. Cullen. 1917. Studies of acidosis. I. The bicarbonate concentration of the blood plasma: its significance, and its determination as a measure of acidosis. J. Biol. Chem. 30: 289-346.

3. Swan, R. L., and R. F. Pitts. 1955. Neutralization of in- 
fused acid by nephrectomized dogs. J. Clin. Invest. 34: 205-212.

4. Schwartz, W. B., R. L. Jenson, and A. S. Relman. 1954. The disposition of acid administered to sodium-depleted subjects: the renal response and the role of the whole body buffers. J. Clin. Invest. 33: 587-597.

5. Goodman, A. D., J. Lemann, Jr., E. J. Lennon, and A. S. Relman. 1965. Production, excretion, and net balance of fixed acid in patients with renal acidosis. J. Clin. Invest. 44: 495-506.

6. Bergstrom, W. H. 1954. The relationship of sodium and potassium to carbonate in bone. J. Biol. Chem. 206: 711-715.

7. Wills, M. R. 1970. Fundamental physiologic role of parathyroid hormone in acid-base homeostasis. Lancet. II: 802-804.

8. Adler, S. 1970. The role of $\mathrm{pH}, \mathrm{pCO}_{2}$, and bicarbonate in regulating rat diaphragm citrate content.J. Clin. Invest. 49: $1647-1655$.

9. Schmidt, R. W., and C. N. Reilly. 1957. New complexon for titration of calcium in the presence of magnesium. Anal. Chem. 29: 264-267.

10. Schloerb, P. R., and J. J. Grantham. 1965. Intracellular $\mathrm{pH}$ measurement with tritiated water, carbon-14 labeled 5,5-dimethyl-2,4 oxazolidinedione, and chloride-36. J. Lab. Clin. Med. 65: 669-676.

11. Adler, S., A. Roy, and A. S. Relman. 1965. Intracellular acid-base regulation. I. The response of muscle cells to change in $\mathrm{CO}_{2}$ tension or extracellular bicarbonate concentration. J. Clin. Invest. 44: 8-20.

12. Bettic, J. A., and J. L. Gamble. 1975. Skeletal buffering of acute metabolic acidosis. Am J. Physiol. 229: 1618-1624.

13. Collip, J. B., and P. L. Backus. 1920. The effect of prolonged hyperpnea on the $\mathrm{CO}_{2}$ combining power of the plasma, the carbon dioxide tension of alveolar air and the excretion of acid and basic phosphate and ammonia by the kidney. Am. J. Physiol. 51: 568-579.

14. Waddell, W. J., and R. G. Bates. 1969. Intracellular pH. Physiol. Rev. 49: 285-329.

15. Weir, E. G., and A. B. Hastings. 1939. The distribution of bromide and chloride in tissues and body fluids. J. Biol. Chem. 129: 547-553.

16. Glynn, I. M. 1956. Sodium and potassium movements in human red cells. J. Physiol. (Lond.). 134: 278-310.

17. Bernstein, R. E. 1954. Potassium and sodium balance in mammalian red cells. Science (Wash. D. C.). 120: 459-460.

18. Relman, A. S., E. J. Lennon, and J. Lemann, Jr. 1961. Endogenous production of fixed acid and the measurement of the net balance of acid in normal subjects. J. Clin. Invest. 40: 1621-1630.

19. Wrong, O., and H. E. F. Davies. 1959. The excretion of acid in renal disease. Q. J. Med. 28: 259-313.

20. Fenn, W. O. 1928. The $\mathrm{CO}_{2}$ dissociation curve of nerve and muscle. Am. J. Physiol. 85: 207-223.

21. Schwartz, W. B., K. J. Ørning, and R. Porter. 1957. The internal distribution of hydrogen ions with varying degrees of metabolic acidosis. J. Clin. Invest. 36: 373-382.

22. Yoshimura, T., M. Fujimoto, O. Okumura, J. Sugimoto, and T. Kuwada. 1961. Three step regulation of acid-base balance in body fluids after acid load. Jpn. J. Physiol. 11: $109-125$.

23. Burnell, J. M. 1971. Changes in bone sodium and carbonate in metabolic acidosis and alkalosis in the dog. J. Clin. Invest. 50: 327-331.
24. Johnston, C. C., Jr., W. P. Deiss, Jr., and R. S. French 1965. Effects of changes in parathyroid status and calcium equilibrium on bone matrix metabolism. Proc. Soc. Exp. Biol. Med. 118: 551-554.

25. Wachman, A., and D. S. Bernstein. 1968. Diet and osteoporosis. Lancet. I: 958-959.

26. Hiatt, H. H., and D. D. Thompson. 1957. The effects of parathyroid extract on renal function in man. J. Clin. Invest. 36: 557-565.

27. Kleeman, C. R., D. Bernstein, R. Rockney, J. T. Dowling, and M. H. Maxwell. 1961. Studies on the renal clearance of diffusable calcium and the role of the parathyroid glands on its regulation. Yale J. Biol. Med. 34: 1-30.

28. Hellman, D. E., W. Y. W. Au, and F. C. Bartter. 1965. Evidence for a direct effect of parathyroid hormone on urinary acidification. Am. J. Physiol. 209: 643-650.

29. Wachman, A., and D. S. Bernstein. 1970. Parathyroid hormone in metabolic acidosis. Its role in $\mathrm{pH}$ homeostasis. Clin. Ortho. P. Relat. Res. 69: 252-263.

30. Simasaki, M., and T. Yagi. 1960. Histochemistry of carbonic anhydrase with special reference to the osteoclast. Dent. Bull. Osaka Univ. 1: 89-98.

31. Waite, L. C., W. A. Volkert, and A. D. Kenny. 1970. Inhibition of bone resorption by acetazolamide in the rat. Endocrinology. 87: 1129-1139.

32. Martin, L., J. Freitag, M. Conrades, S. Klahr, and E. Slatopolsky. 1978. Acidosis enhances the uptake and biologic effect of PTH in isolated perfused bone. Abstracts for the American Society of Nephrology. 11: 7A.

33. Swan, R. C., H. Madisso, and R. F. Pitts. 1954. Measurement of extracellular fluid volume in nephrectomized dogs. J. Clin. Invest. 33: 1147-1156.

34. Cohen, R. D., and R. A. Iles. 1975. Intracellular pH; measurement, control, and metabolic interrelationships. CRC Crit. Rev. Clin. Lab. Sci. 6: 101-143.

35. Bergstrom, W. H., and W. M. Wallace. 1954. Bone as a sodium and potassium reservoir. J. Clin. Invest. 33: $867-873$.

36. Raisz, L. G. 1972. Calcium, phosphate, magnesium and trace elements. In Clinical Disorders of Fluid and Electrolyte Metabolism. M. Maxwell and C. R. Kleeman, editors. McGraw-Hill Book Company, New York. 2nd edition. 347-400.

37. Epel, S. 1977. The program of fertilization. Sci. Am. 237: $128-138$.

38. Waters, W. C., III, J. D. Hall, and W. B. Schwartz. 1963. Spontaneous lactic acidosis: the management of the acid base disturbance and considerations in diagnosis and management. Am J. Med. 35: 781-793.

39. Garella, S., C. L. Dana, and J. A. Chazan. 1973. Severity of metabolic acidosis as a determinant of bicarbonate requirements. N. Engl. J. Med. 289: 121-126.

40. Adrogue, H. J., N. E. Madias, J. Brensilver, and J. J. Cohen. 1977. Evidence that acidemia per se is not responsible for the increased bicarbonate space in metabolic acidosis. Abstracts for the American Society of Nephrology. 10: $94 A$.

41. Giebisch, G., L. Berger, and R. F. Pitts. 1955. The extrarenal response to acute acid base disturbances of respiratory origin. J. Clin. Invest. 34: 231-245.

42. Tobin, R. B. 1956. Plasma, extracellular, and muscle electrolyte responses to acute metabolic acidosis. Am. J. Physiol. 186: $131-138$.

43. Cohen, R. D., R. A. Iles, D. Barnett, M. E. O. Howell, and J. Strunin. 1971. The effect of changes in lactate uptake on 
the intracellular pH of the perfused rat liver. Clin. Sci. 41: 159-170.

44. Levitt, M. F., L. B. Turner, A. Y. Sweet, and D. Pandiri. 1956. The response of bone, connective tissue, and muscle to acute acidosis. J. Clin. Invest. 35: 98-105.

45. Skelton, H. 1927. The storage of water by various tissues of the body. Arch. Intern. Med. 40: 140-152.

46. Roos, A. 1971. Intracellular $\mathrm{pH}$ and buffering power of rat muscle. Am. J. Physiol. 221: 182-188.
47. Chase, L. R., S. A. Fedak, and G. D. Aurbach. 1969. Activation of skeletal adenyl cyclase by parathyroid hormone in vitro. Endocrinology. 84: 761-768.

48. Morris, R. C., Jr., E. McSherry, and A. Sebastian. 1971. Modulation of experimental renal dysfunction of hereditary fructose intolerance by circulating parathyroid hormone. Proc. Natl. Acad. Sci. U. S. A. 68: 132-135.

49. Reiss, E., J. M. Canterbury, and A. Kanter. 1969. Circulating parathyroid hormone concentration in chronic renal insufficiency. Arch. Intern. Med. 124: 417-422. 